\title{
Application of the Pitman Model to Generate Discharges for the Lhasa Basin, China
}

\section{Luna Bharati / Nilantha Gamage}

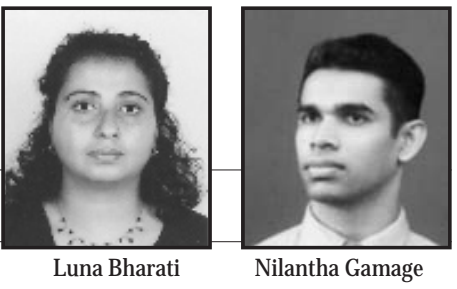

Abstract: Predicting river flows in basins where limited data is available is a challenge facing many hydrologists especially in developing countries. In this study, the Pitman monthly model was applied to generate flows for the Lhasa basin in China (Tibet). As flow data was unavailable for the Lhasa basin, the model was first calibrated for the upper Koshi Basin in Nepal and China. The Pitman model successfully predicted flows for the upper Koshi basin $\left(R^{2}=0.88\right)$. Therefore, the estimated model parameters from the Koshi basin as well as climate data from the Lhasa basin were used to generate flows for the Lhasa basin outlet. The main modeling assumption is that the basin characteristics of the upper Koshi are similar to that of the Lhasa basin. Under present circumstances, where measured data is unavailable, the model estimated monthly flows for the Lhasa basin can be used in further studies in basin water accounting and management.

Key words: Un-gauged basins, Pitman monthly model, stream flow generation, Lhasa basin (Tibet), Koshi basin (Nepal)

\section{Introduction}

The flow regime is recognized as a key factor in determining biological and physical processes and characteristics in rivers (Snelder et al 2005, Biggs 1996, Hildrew and Townsend 1987). Accurate estimates of stream flow and the related hydrologic variables are also very important for water resources planning and management. However, measured flow data that can be used to characterize flow regimes are unavailable for many ungauged locations. Predicting stream flow in ungauged basins is a significant challenge facing hydrologists especially working in developing countries.

The aim of this study is to generate river flows using the Pitman monthly rainfall-runoff model for the Lhasa catchment in Tibet, China. Although, therearerivergaugingstationsin the Lhasa catchment, records of river discharge are not

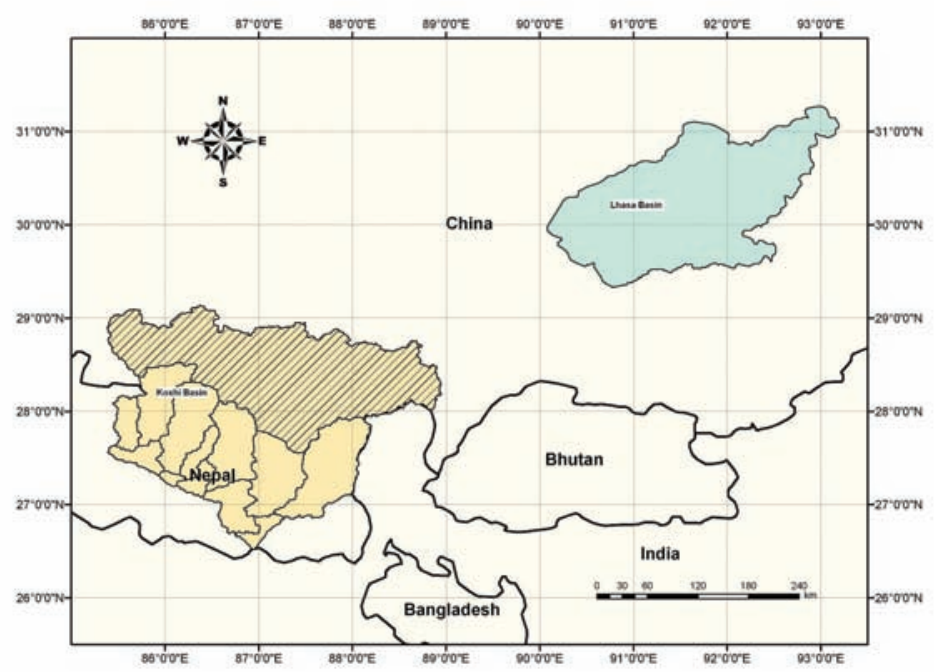

Figure 1. The Koshi and Lhasa Basins, Highlighted Area in the Koshi Basin is the Modeled Upper Sub-catchment where Agro-Ecology is Similar to Lhasa Basin. accessible. The Koshi basin in Nepal and China has similar characteristics as the Lhasa catchment. (Figure 1 shows the location of the Lhasa and Koshi basins.) Therefore, in order to generate discharge for the Lhasa catchment, the Pitman model was first calibrated using rainfall-runoff data from the Koshi Basin. The calibrated model parameters from the Koshi basin as well as climate data from the Lhasa basin were then used to generate flows in Lhasa basin.

The simulated monthly discharge curves can be used to understand rainfall-runoff responses in the study catchments. Furthermore, the monthly flow volumes can be used for water accounting and management by comparing total water availability (simulated from the model) to water use/demand from the different water use sectors in the basin.

\section{Methodology}

The SPATSIM (Spatial and Time Series Information Modeling) software was used in this study. SPATSIM was developed at the Institute for Water Research (IWR) at Rhodes University, South Africa (IWR 2005). It is an integrated data management and modeling software package developed in Delphi using the spatial data handling functions of Map Objects. SPATSIM includes several external model and data analysis tools, one of which is the Pitman Model.

\section{The Pitman Model}

TheIWRsemi-distributed version of thePitman model was applied in thisstudy. This model is a conceptual model which runs on monthly values. Similar to many other conceptual models, the Pitman (1973) model consists of 
storages linked by functions designed to represent the main hydrological processes prevailing at the basin scale. Compulsory data requirements for the rainfall-runoff model include catchment area, a time series of catchment average rainfall, a time series of potential evaporation, or an annual value and monthly distributions. Optional requirements include seasonal distributions of irrigation water requirements and other water abstractions, as well as time series of upstream inflow, transfer inflow and downstream compensation flow requirements. Figure 2 shows a flow diagram of the main components of the SPATSIM version of the Pitman model. The list of parameters for the rainfall-runoff and a brief description is provided in Table 1. Further information regarding the Pitman model and the SPATSIM software can be found in Pitman (1976) and Hughes, Andersson and Savenije (2006).

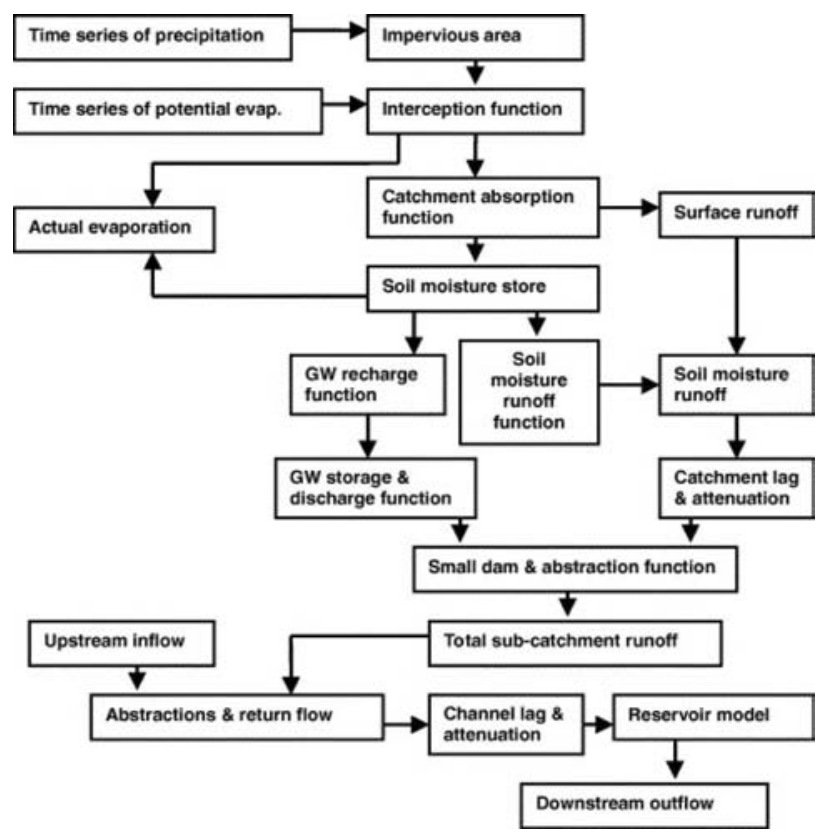

Figure 2 : Flow Diagram of the main components of the SPATISM version of the Pitman Model

\section{Model setup in the Koshi basin}

The Koshi basin lies in China (Tibet) and Nepal and is characterized by high climatic and geographical variability. The main assumption in this study is that the basin characteristics of Koshi are similar to that of the Lhasa catchment. Rainfall data from the southern part of the Koshi basin was significantly higher than in the northern or upper sub-catchment. It was assumed that the upper sub-catchment of the Koshi basin (around $34,000 \mathrm{~km}^{2}$ ) is more similar to the Lhasa catchment $\left(34,396 \mathrm{~km}^{2}\right)$. Therefore, as the calibrated parameters from the Koshi basin were going to be used to generate flows for the Lhasa basin, only the upper sub-catchments of the Koshi, upstream of the flow station at Arun river
Table 1. Pitman Model Parameters used for Modeling the Lhasa and Koshi Basins

\begin{tabular}{lll}
\hline Parameter & Model Parameter Description & $\begin{array}{l}\text { Default } \\
\text { Value }\end{array}$ \\
\hline RDF & Rain Distribution Factor & 1.2 \\
Al & Proportion of impervious area & 2.2 \\
PI1s & Summer intercept storage(Veg1) & 1.5 \\
PI1w & Winter intercept storage(Veg1) & 1.5 \\
PI2s & Summer intercept storage (Veg2) & 4 \\
PI2w & Winter intercept storage (Veg2) & 4 \\
AFOR & \% Area of Veg2 & 15 \\
FF & Veg2/Veg1 Pot. Evap. Ratio & 1 \\
& Power of Veg recession curve & 1 \\
PEVAP & Annual Pan Evaporation (mm) & 700 \\
ZMINs & Summer min.abs.rate (mm/mth) & 40 \\
ZMINw & Winter min.abs.rate (mm/mth) & 5 \\
ZAVE & Mean abs. rate (mm/mth) & 30 \\
ZMAX & Maximum abs.rate (mm/mth) & 120 \\
ST & Maximum storage capacity & 200 \\
SL & No runoff below storage & 0 \\
POW & Power : storage-runoff curve & 1.5 \\
FT & Runoff rate at ST (mm/mth) & 30 \\
GW & Max. groundwater flow (mm/mth) & 5 \\
R & Evaporation-storage coefficient & 0.5 \\
TL & Surface runoff time lag (months) & 1.5 \\
GL & Groundwater time lag (months) & 2 \\
AIRR & Irrig. area (km^2) & 0 \\
IWR & Irrig. return flow fraction & 0 \\
EFFECT & Effective Rainfall fraction & 0.5 \\
MI/year & Non-Irrig. Direct Demand & 0.75 \\
& Maximum dam storage (Ml) & 0 \\
& \% Catchment area above dams & 0 \\
& A in area volume relationship & 0 \\
& B in area volume relationship & 0 \\
& Irrig. Area from Dams (km^2) & 0 \\
\hline & & \\
& &
\end{tabular}

at Uwa Gaon, was modeled. A digital elevation model (DEM) was used to delineate the sub-watersheds as well as the drainage network. Figure 1 shows the upper subcatchment in the Koshi. Rainfall data from Phidim, Lazi, Dingri, Num and Taplethok stations were interpolated for the upper sub-catchment using the inverse distance weighting procedure. The temporal time-frame for the modelingexercisewasfrom 1985-1995. Penman-Montieth reference evapotranspiration rates were used based on the World Water and Climate Atlas (IWMI 2000). The irrigation fraction that comprises the main water abstraction component was estimated based on personal communication with scientists at the International Center for Integrated Mountain Development (ICIMOD; Xu Jianchu, pers. comm.). The required model parameters were determined based on values in the literature as well as using best judgment.

The complete period from 1985-1995 was used for calibration. The manual calibration guidelines provided by Pitman (1973) indicate which aspects of the simulation results are dominantly affected by changes to different 
parameter values. Several model parameters should be determined using measured values and remain fixed during the calibration period. These fixed parameters include drainage density (d.Dens), groundwater transmisssivity (T), and groundwater storativity (s). However, due to a lack of measured information on aquifer and soil properties, somecalibration was necessary. Themain calibrated parameters included surface runoff (ZMIN, ZAVE, ZMAX), soil moisture storage and runoff function (ST, POW, FT), and groundwater recharge (GPOW, GW). The fit between observed and simulated flow was mainly evaluated using coefficient of determination (R2) and by visually adjusting the simulated hydrographs.

\section{Model setup in the Lhasa Basin}

The Lhasa basin is situated in the Tibetan Plateau in China. It is a sub-basin of the Brahmaputra basin and was chosen as a pilot study area for the Brahamatwinn Project. Although several flow stations exist in the basin, data was unavailable except from one gauging station draining a very small subwatershed. The discharge data from the outlet of the Lhasa basin was not available. Rainfall data was available from Danxioung, Gongga, Lhasa, Monzhugong, Nimu and Panduo. The modeling time frame was from 19851995. Similar to the Koshi basin, the rainfall data was interpolated using the inverse distance weighting method and potential evaporation values were obtained from the IWMI climate atlas. The irrigation fraction was again estimated based on personal communication with ICIMOD scientists (Xu Jianchu, pers. comm.).

\section{Results}

Figure 3 shows the correspondence between observed and simulated flow for the upper Koshi sub-catchment. The coefficient of determination $\left(\mathrm{R}^{2}\right)$ is 0.88 , which

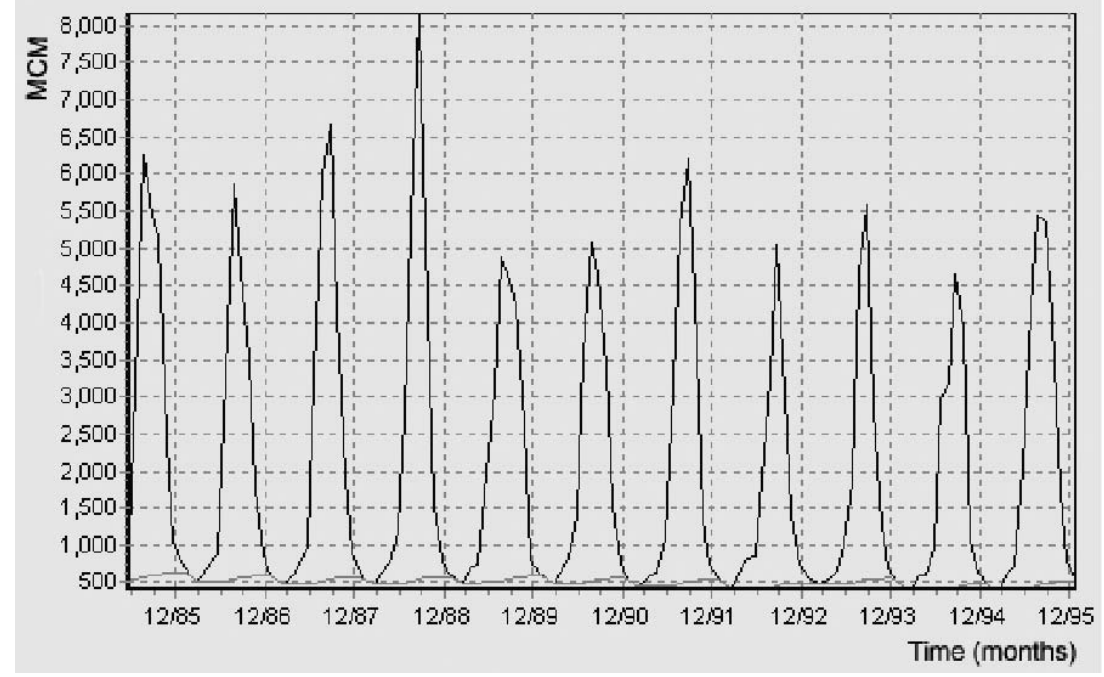

Figure 5. Baseflow Analysis for the Koshi Upper Sub-Catchment.

shows very good results for the calibration. The observed vs. simulated monthly flows can be seen in Figure 4. The simulated Hydrographs (Figure 4) show that base flow is slightly overestimated. Further calibration of the model was not done as a very low groundwater recharge rate was used. Figure 5 shows the simulated base flow component 


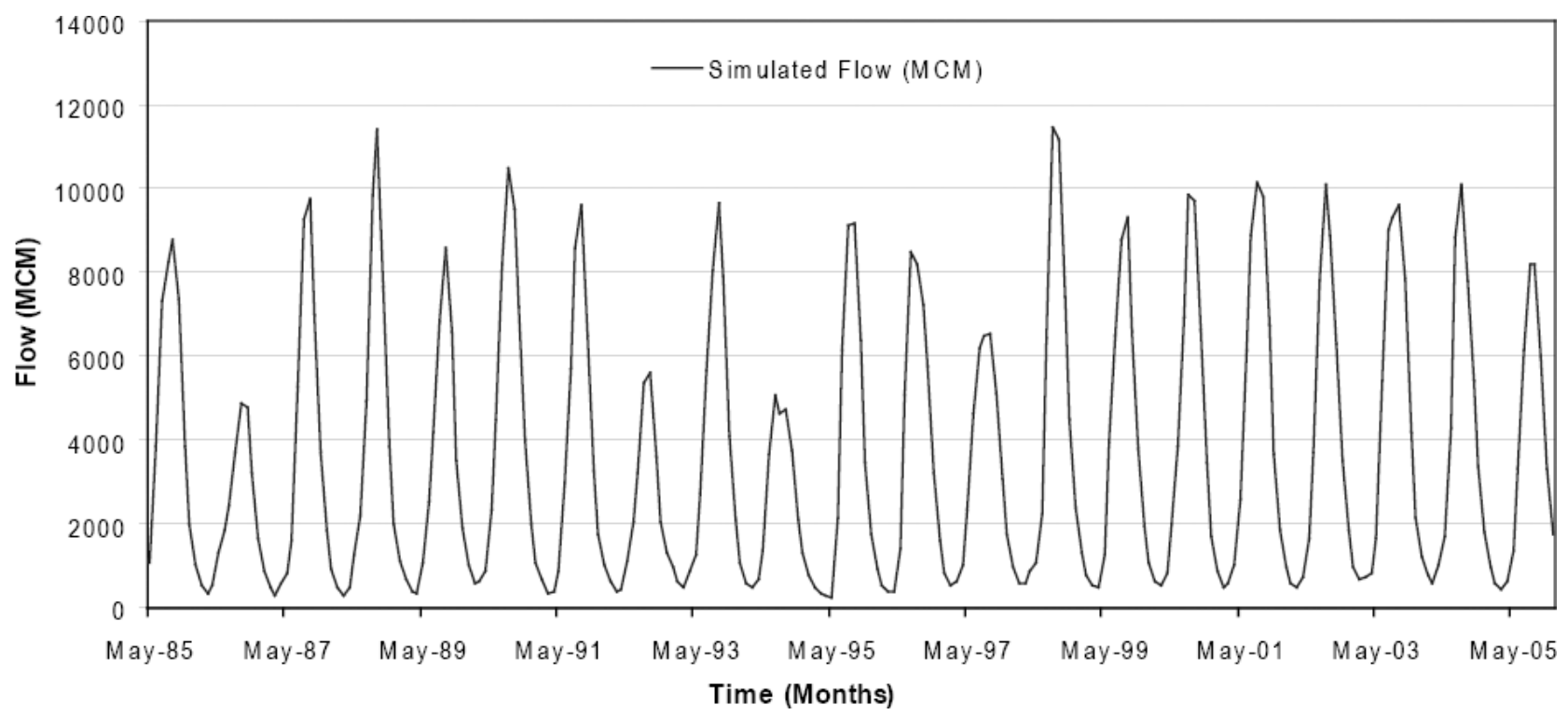

Figure 6. Simulated Monthly Flow Volumes in Million Cubic Meters (MCM) for the Outlet Point of the Lhasa Basin.

for the upper Koshi sub-catchment. Over estimation of base flow could be due to groundwater extraction which was not included in the model. It can be seen that the stormflow component of the flows is more important than the base flow component.

The calibration results were thought to be acceptable for the model to be applied to the Lhasa basin. The simulated flow volumes Million Cubic Meters (MCM) for the Lhasa basin are shown in Figure 6. The interannual variability in the discharges is primarily due to the variability in rainfall. Normally, with any modeling exercise, there is a need for validation. As data from the Lhasa basin is measured, it would add to the reliability of the results if the simulated flows could be validated for even a limited time frame. Nevertheless, under the present circumstances, where measured data is unavailable, the model estimated monthly flows is very valuable for further studies that depend on information about the total water availability in the catchment.

\section{Conclusions}

The study demonstrates that the Pitman monthly model can be successfully applied to catchments in the study area. Although, there is some uncertainty in the generated flows for the Lhasa basin as validation with measured flow data was not possible, the modeling outputs are still useful in estimating total water availability for the Lhasa catchment. The modeling results can be improved if measured values are available in the future for the input parameters needed for the model. The methodology described in this paper can be applied to other studies in un-gauged river basins where flow data is not available.

Luna Bharati, $\mathrm{PhD}$, Researcher - International Water Management Institute, IWMI-Nepal. Ms Bharati has over 12 years of experience in projects related to natural resources and land and water management. She has a Masters degree in Water Resources from Iowa State University, USA, and a Doctorate from the Faculty of Agriculture, Martin Luther University of Halle-Wittenburg, Germany, focusing on surface hydrology, erosion and pollutant transport. Luna has worked in projects in Nepal, USA, Germany, India, Bangladesh, China, Ghana and Burkina Faso. Her key areas of interest and expertise are: establishing and maintaining field observation networks for hydrological and meteorological monitoring; field investigation and modeling of erosion and nutrient transport and the impacts on water quality (models used: AGNPS, Erosion 3D); modeling the water balance of a catchment and the influence of climate and land use change using distributed watershed models (e.g. WaSim-ETH, SWAT, GeoSFM, WEAP); developing integrated environmental and economic models for calculating optimal water use and allocation for decision support systems; and calculating environmental flow requirements in the context of basin water allocation strategies Corresponding address: L.bharati@cgiar.org

Nilantha Gamage, $M$ Tec, Research Officer - IWMI, Colombo, Sri Lanka. Mr Gamage is a Research Officer attached to IWMI's Global Research Division. He did his M Tech degree in Remote Sensing and GIS from Andhra University, Visakapatnam, India, and is currently pursuing his $\mathrm{PhD}$ at the School of Engineering and Science, Victoria University, Melbourne Australia. His interests are in application of remote sensing and GIS for hydrological modeling and water resources management. He is specialized in applying remote sensing and GIS techniques to calculate actual evapotranspiration, LULC classification and drought analysis. Currently, he is involving in application of 
remote sensing and GIS to generate stream flow data in data scare watersheds.

Corresponding address: n.gamage@cgiar.org

\section{Acknowledgements}

This study was funded by The International Centre for Integrated Mountain Development (ICIMOD). The authors are grateful to $\mathrm{Dr} \mathrm{Xu}$ Jianchu and $\mathrm{Dr}$ Mats Eriksson for supporting this work and providing necessary data.

\section{References}

Biggs, B.J F., 1996, Hydraulic habitat of plants in streams, Regulated Rivers: Research and Management, v.12, pp.131-144.

Hildrew, A.G. and C.R. Townsend, 1987, Organization in freshwater benthic communities, pp.347-371 in J.H.R. Gee and P.S. Giller, eds., Organization of Communities Past and Present, Oxford, UK: Blackwell.

Hughes, D.A., L. Andersson, J. Wilk and H.HG. Savenije, 2006, Regional calibration of the Pitman model for the Okavango River, Journal of Hydrology, v.331, pp.30-42.

IWMI, 2000, World Water and Climate Atlas (2 vols.), Colombo, Sri Lanka: International Water Management Institute. (URL: www.iwmi.cgiar.org/ WAtlas/atlas.htm)

IWR, 2005, SPATSIM: Spatial and Time Series Information Modeling Software, Institute for Water Research, Rhodes University, Grahamstown, South Africa. (URL: www.ru.ac.za/institutes/iwr/software/ spatsim.html)

Pitman, W.V., 1973, A Mathematical Model for Generating River Flows from Meteorological Data in South Africa, Report No. 2/73, Hydrological Research Unit, University of the Witwatersrand Johannesburg, South Africa.

Smakhtin,V.U.andM.Anputhas, 2006,AnAssessment of Environmental Flow Requirements of Indian River Basins, IWMI Research Report 107, International Water Management Institute, Colombo, Sri Lanka, pp. 36

Snelder, T.H., B.J.F. Biggs and R.A. Woods, 2005, Improved eco-hydrological classification of rivers, River Research and Applications, v.21, pp.609-628.

\section{GALENDAR ENERGY}

24-27 Aug. 2010, Training on Regulations in Electricity Sector with specific reference to Renewable Energy, Roorkee, India. More info: http://ahec.org. in/

12-16 Sept. 2010. World Energy Congress, Location: Montreal, Quebec, Canada. More Info: www.wecmontreal2010.ca

19-21 Oct. 2010, EFEF 2010 (European Future Energy Forum), Location: London, United Kingdom
More info:www.europeanfutureenergyforum.com/

27-30 Oct. 2010, 12th Int. Exhibition Conference; Theme: Power \& Energy Efficiency; CEO's Forum Theme: Power \& Climate Change; Mumbai, India: E mail : info@indiapowershow.com

19-23 Sept. 2010:10th International Conference on Greenhouse Gas Control Technologies, RAI, Amsterdam, Netherlands. More info: www.ghgt.info/ GHGT10.html

\section{CALENDAR WATER SUPPLY \& RAINWATER HARVESTING}

12-14 July, 2010: Waste Management 2010, Fifth International Conference on Waste Management and Environment. Location: Tallinn, Estonia. More Info: www.wessex.ac.uk/10-conferences/wastemanagement-2010.html

11 - 16 J uly 2010, 13th SearNet International Conference; Theme is: Rainwater Harvesting as a Means of Adaptation to the Challenges of Climate Change. Location: Awassa, Ethiopia. More info Contact: www.rainfoundation.org

28 March - 4 Apri 2011 15th International Conference on Rainwater Catchment Systems, More info:
E-mail: andrewlo@faculty.pccu.edu.tw and web: http://www.ircsa.org/conference_roc.html

Sept. 2010: International Rainwater Harvesting Alliance (IRHA) \& Watershed Organization Trust (WOTR) are jointly organizing a training/workshop on : Rainwater Harvesting in the heart of the Micro Farmingand Food Securityin Watershed Development Programmes.; Training in India

CD ROM Training Course on Water Harvesting released by the Food and Agriculture Organization

The CD ROM can be obtained from FAO at http:// www.fao.org/landandwater/lwdms.stm\#cd26 or by contacting Ines Beernaerts at FAO 